\title{
IDENTIFICATION AND FUNCTIONAL CHARACTERIZATION OF GERMLINE GENETIC VARIANTS PREDISPOSING TO DIFFERENTIATED THYROID CANCER RISK
}

\author{
GISELLA FIGLIOLI (*), et al." \\ Nota presentata dal s.c. Andrea Mattevi \\ (Adunanza del 3 novembre 2016)
}

\begin{abstract}
SuNTO. - Il carcinoma tiroideo differenziato (DTC) è il tumore endocrino più frequente ed in Italia si registra una elevata incidenza. Il rischio d'insorgenza di questa malattia è significativamente maggiore nei parenti di primo grado degli individui affetti suggerendo che anche le varianti genetiche germinali possano contribuire alla sua insorgenza. Precedenti studi di associazione sull'intero genoma (GWASs) hanno permesso l'identificazione di polimorfismi a singolo nucleotide (SNPs) associati con il rischio di DTC localizzati nelle regioni $2 \mathrm{q} 35$, 9q22.33 e 14q13.3. Al fine di individuare nuovi loci di suscettibilità al DTC, è stato eseguito un GWAS sulla popolazione italiana. In seguito, gli SNPs più interessanti sono stati analizzati in una popolazione italiana più ampia e in altre casistiche europee. I risultati di questo studio hanno confermato il ruolo del loci 2q35 e 9q22.33 nella suscettibilità al DTC. Inoltre, i polimorfismi nelle regioni $14 \mathrm{q} 24.3$ e $20 \mathrm{q} 11.22-\mathrm{q} 12$ sono risultati associati ad un incremento del rischio di DTC nell'analisi combinata di tutte le popolazioni analizzate, e gli SNPs localizzati in $3 \mathrm{q} 25.32,5 \mathrm{q} 14,7 \mathrm{q} 21,9 \mathrm{q} 34.3,11 \mathrm{p} 15,13 \mathrm{q} 12.12$ e $20 \mathrm{p} 11$ sono risultati associati alla malattia soltanto negli Italiani. Secondo i dati del progetto ENCODE, molti di questi polimorfismi si trovano all'interno di regioni di regolazione della trascrizione e lo studio delle eQTL ha mostrato che cinque degli SNPs identificati in questo studio sono associati alla regolazione dei loro geni più vicini in diversi tessuti, compreso il tessuto tiroideo. In conclusione, tramite questo studio sono stati identi-
\end{abstract}

(*) IFOM, the FIRC Institute of Molecular Oncology, Milan, Italy.

E-mail: gisella.figlioli@ifom.eu

(*) La nota è il risultato di un lavoro di ricerca condotto in collaborazione con: Aleksandra Köhler, Bowang Chen, Rossella Elisei, Cristina Romei, Kari Hemminki, Stefano Landi, Asta Försti, Federica Gemignani. 
ficati nuovi alleli di suscettibilità al DTC ed è stato proposto un loro possibile ruolo funzionale.

$* * *$

ABSTRACT. - Differentiated thyroid cancer (DTC) is the most common endocrine tumor, showing a high incidence in Italy. A significant higher risk of this cancer is described in first-degree relatives of DTC patients compared to the general population suggesting that germline genetic variants may contribute to its development. Previous genome-wide association studies (GWASs) on DTC have identified robust associations with single nucleotide polymorphisms (SNPs) at chromosomes 2q35, 9q22.33 and 14q13.3. In order to identify additional DTC susceptibility loci, a novel GWAS on the Italian population was conducted. The GWAS was followed by validation studies, where the most interesting SNPs were replicated in a larger Italian population and other European cohorts. Previously observed association for $2 \mathrm{q} 35$ and $9 \mathrm{q} 22.33$ was confirmed. Moreover, a strong relationship of DTC risk was found with SNPs on 14q24.3 and 20q11.22-q12 across all populations and SNPs on $3 \mathrm{q} 25.32,5 \mathrm{q} 14,7 \mathrm{q} 21,9 \mathrm{q} 34.3,11 \mathrm{p} 15,13 \mathrm{q} 12.12$ and $20 \mathrm{p} 11$ only among Italians. According to ENCODE Project data, many of these SNPs are located in transcription regulatory regions and eQTL analyses showed that five of the associated SNPs may affect the expression levels of their closest genes in different human tissues, including thyroid. In conclusion, novel DTC risk alleles were identified and new insights into their possible functional role were discovered.

\section{INTRODUCTION}

Thyroid cancer (TC) comprises approximately $1 \%$ of all human malignancies and it is the most common endocrine malignancy, representing up to $80 \%$ of all cancers originating from endocrine organs [1]. Worldwide, thyroid cancer incidence varies in different geographic regions and it is overall higher in more economically developed countries. In Europe particularly elevated age-standardised rates (ASRs) were observed in Lithuania (ASR=15.5/100,000), Italy (ASR=13.5/ 100,000) and Austria (ASR=12.4/100,000) (http://eco.iarc.fr/EUCAN/ and http://globocan.iarc.fr).

Approximately $90 \%$ of diagnosed TCs arise from the thyrocytes, the thyroid hormone-producing cells, and are classified as differentiated thyroid cancers (DTCs). Among them, the most frequent subtype is papillary (PTC, 75\%), followed by follicular (FTC, 10\%), Hurthle cells $(5 \%)$, and poorly differentiated carcinomas $(1 \%-6 \%)$. Only a small proportion of TCs, called medullary thyroid cancer (MTC), originates from thyroid parafollicular cells [2].

There are few known TC risk factors except for exposure to ionizing radiation, female gender and a previous benign thyroid disease 
[3]. Interestingly, TC is characterized by having one of the highest heritability among all cancer sites, as demonstrated by a significantly higher risk in first-degree relatives of patients with DTC than in the general population and suggesting that also germline genetic variants (e.g. single nucleotide polymorphisms, SNPs) may contribute to the risk of the disease [4].

In order to identify SNPs associated with DTC genetic predisposition case-control association studies were conducted [5]. To date, candidate gene/pathway association studies remain the most prevalent type of investigation with more than 100 studies published and more than 300 SNPs examined. Of them, SNPs within genes involved in DNA repair pathways, cell-cycle control, xenobiotic metabolism and in the MAPK pathway were frequently investigated. While some of these variants could represent true associations with DTC, many failed to be replicated among additional populations and could be false-positive [6].

During the past decade genome-wide association studies (GWASs) emerged worldwide as an unbiased approach, independent of a priori knowledge on the disease, to reveal SNPs and genomic regions associated with human cancer risk. GWASs rely on the phenomenon of linkage disequilibrium (LD) wherein SNPs are not inherited individually but instead are in LD blocks, with many nearby SNPs being highly correlated. This allows obtaining information on $\sim 50,000$ variants by analyzing only one SNP (formally named "tag-SNP") and therefore it may be used to study the entire genome by evaluating 500,000-700,000 tag-SNPs [7]. GWASs are commonly performed using a multistage approach. In the first stage (e.g. the discovery phase), all tag-SNPs are tested on a small subset of cases and control. During the second stage (e.g. the validation phase), significant tag-SNPs, are analyzed in a population similar to that used in the previous phase with the purpose of ruling out false positive associations. Moreover, validations in different populations represent also an important task to check if the observed effects are specific for the discovery population or if they may be extended to different geographic groups $[8,9]$. Once the association of a SNP is confirmed, the next challenge lies in discovering its functional role and in the identification of its target gene. While few GWAS-identified SNPs are predicted to disrupt protein-coding regions, the great majority of them, approximately $88 \%$, lie in intergenic or intronic regions and could be located within transcriptional regulatory elements (such as promoters, enhancers, transcription factor binding sites [TFBSs] and DNaseI hypersensitive sites [DHSs]). 
All these functional elements of the human genome were annotated by the ENCODE (ENCylopedia Of DNA Elements) project and they could be mined to uncover the possible functional role of GWAS-identified SNPs $[10,11]$. Moreover, it was clearly reported that inherited genetic variants within several genomic regions, called expression quantitativetrait loci (eQTLs), are associated with expression of many transcripts. Thus, studying the associations between SNPs and gene expression levels may represent a useful way to connect risk variants to their putative genes or transcripts. eQTLs can be located either near $(1 \mathrm{Mb})$ the gene they regulate (cis-eQTL) or at a significant distance away from it (trans-eQTL) $[12,13]$. At this regard, the Genotype-Tissue Expression (GTEx) program has recently provided expression levels of human genes in transformed fibroblasts and in several tissues from healthy individuals allowing the characterization of the eQTLs and the interpretation of GWASidentified SNPs [14].

In 2009 Gudmusson and collaborators published the first GWAS on DTC. The strongest signals were found for the SNP rs965513 on 9q22.33, $57 \mathrm{~kb}$ upstream FOXE1 with $(\mathrm{OR}=1.75,95 \%$ CI 1.59-1.94) and rs944289 on $14 \mathrm{q} 13.3$, near NKX2-1 (OR=1.37, 95\% CI 1.24- 1.52) [15]. The importance of FOXE1 in the disease genetic predisposition was confirmed in a second GWAS performed on radiation-related PTCs. In particular, the association for rs965513 was confirmed $(\mathrm{OR}=1.65,95 \% \mathrm{CI} 1.43-1.91)$ and a statistically significant association was found for rs 1867277 (OR=1.48, 95\% CI 1.27-1.71) [16]. Additional DTC risk variants were found through a GWAS on circulating TSH levels. In this study the strongest association was observed for rs 116909374 on $14 \mathrm{q} 13.3$ with an OR of 2.09 (95\% CI 1.68-2.60). Similarly, the variants rs 966423 on $2 \mathrm{q} 35$ (within DIRC3) and rs2439302 on 8p12 (within NRG1) were significantly associated with DTC with OR of $1.34(95 \%$ $1.22-1.47)$ and 1.36 (95\% CI 1.23-1.50), respectively [17].

In order to search for additional variants predisposing to DTC a novel GWAS on the high-incidence Italian population was performed thanks to a successful collaboration among the Department of Endocrinology and Metabolism of the University Hospital Cisanello of Pisa (Italy), the Department of Biology of the University of Pisa (Italy) and the Division of Molecular Genetic Epidemiology of the German Cancer Research Center (DKFZ, Heidelberg, Germany). The GWAS was followed by the replication of SNPs that showed suggestive evidence of association in other European cohorts and by the assessment 
of the cumulative effect of the identified SNPs. The functional role of the best-associated SNPs was also investigated by using ENCODE project experimental data and by eQTL analyses.

\section{RISK VARIANTS ASSOCIATED WITH DIFFERENTIATED THYROID CANCER RISK}

The local Ethical Committee approved this study and all participants gave their written informed consent to participate according to Helsinki declaration.

The discovery phase of the GWAS was performed on Italian histologically confirmed DTC patients and healthy controls. A total of 701 cases were recruited at the Department of Endocrinology and Metabolism of the University Hospital Cisanello in Pisa. The control group comprised 499 healthy individuals without any thyroid disease and cancer history and included workers who underwent a routine check-up at the same hospital of Pisa and blood donors from the Meyer Hospital in Florence. After the application of strict quality controls 572,042 SNPs were analyzed for association with DTC in 690 cases and 497 controls. The results of this phase confirmed the role of the SNPs identified in previous GWASs on DTC predisposition. In particular, a robust evidence for a relationship between FOXE1 and the risk of the disease with multiple SNPs annotating in the region having $p$ value $<5.0 \times 10^{-8}$. Because the association between FOXE1 and DTC was already well-established, SNPs in this region were excluded from the following phases of analysis (Fig. 1) [18].

Validation studies were conducted on four European cohorts. The Italian cohort (Italian1+Italian2) included 1,539 patients and 1,719 controls collected in the same hospitals of the samples of the discovery phase. The Polish group comprised 468 patients with DTC and 470 healthy controls from the Department of Nuclear Medicine and Endocrine Oncology, Maria Sklodowska-Curie Memorial Cancer Center and Institute of Oncology in Gliwice. The Spanish cohort consisted of 446 patients, recruited at the Department of Genetics and Microbiology of Autonomous University of Barcelona, and 420 healthy individuals. The United Kingdom series consisted of 509 cases, ascertained through the Institute of Cancer Research/Royal Marsden Hospital National Health Service Trust, and 1,118 controls recruited through the National Study of 
Colorectal Cancer. A total of 109 SNPs, selected within regions showing stronger association signals (e.g. lower $p$-value) with DTC risk, were validated in the larger Italian population. Of them, 24 SNPs positively replicate the GWAS associations and were also analyzed in Polish, UK and Spanish cohorts. The joint analysis of all populations $(2,985$ cases and 3,727 controls) revealed a genome-wide significant association with DTC for rs6759952 near DIRC3 on $2 \mathrm{q} 35$ (OR=1.25, 95\% CI 1.16-1.34, $p$ value $\left.=6.4 \times 10^{-10}\right)$, rs10136427 near BATF on $14 \mathrm{q} 24.3(\mathrm{OR}=1.30,95 \% \mathrm{CI}$ 1.17-1.44, p-value $=9.30 \times 10^{-7}$ ) and rs7267944 near DHX35 on 20q11.22$\mathrm{q} 12\left(\mathrm{OR}=1.32,95 \% 1.20-1.46\right.$, $p$-value $\left.=1.34 \times 10^{-8}\right)$. The role of the SNPs was also assessed only in the Italian population, totaling 2,260 cases and 2,218 controls. The most significant associations were observed for rs7617304 upstream RARRES1 on 3q25.32 (OR=1.25, 95\% CI 1.12-1.39, p-value $\left.=4.6 \times 10^{-5}\right)$, rs 13184587 within $A R S B$ on $5 \mathrm{q} 14.1(\mathrm{OR}=1.28,95 \% \mathrm{CI}$ $1.15-1.43$, p-value $\left.=8.54 \times 10^{-6}\right)$, rs $10238549(\mathrm{OR}=1.27,95 \%$ CI 1.15-1.40, p-value $=4.1 \times 10^{-6}$ ) and rs7800391 downstream IMMP2L on $7 \mathrm{q} 21$ $\left(\mathrm{OR}=1.25,95 \%\right.$ CI 1.14-1.38, p-value $\left.=5.7 \times 10^{-6}\right)$, rs 10781500 downstream SNAPC4 on $9 \mathrm{q} 34.3\left(\mathrm{OR}=1.23,95 \%\right.$ CI $1.12-1.36$, p-value $\left.=3.5 \times 10^{-5}\right)$, rs7935113 within GALNTL4 on 11p15.3 (OR=1.36, 95\% CI 1.20-1.53, pvalue $\left.=7.41 \times 10^{-7}\right), \mathrm{rs} 1220597$ within SPATA13 on $13 \mathrm{q} 12.12(\mathrm{OR}=1.26$, $95 \%$ CI $1.14-1.38$, $p$-value $\left.=3.25 \times 10^{-6}\right)$ and rs 1203952 upstream FOXA2 on 20p11 $\left(\mathrm{OR}=1.29,95 \%\right.$ CI 1.16-1.44, p-value $\left.=4.42 \times 10^{-6}\right)($ Tab. 1) $[18$ 20]. The cumulative effect of the 11 independent susceptibility SNPs in 10 genes identified in the Italian population was also evaluated. A dosedependent increase in risk of DTC was observed with an increasing number of risk alleles $\left(\mathrm{OR}=1.30,95 \%\right.$ CI $1.26-1.35$, p-trend $\left.=3.13 \times 10^{-47}\right)$. In particular, individuals carrying $\geq 14$ risk alleles had 7.68 times higher risk of getting DTC as compared to those with $\leq 7$ risk alleles (Fig. 2) [19].

\section{BIOINFORMATIC AND EQTL ANALYSES OF THE RISK VARIANTS}

Computational approaches were employed to functionally annotate the associated SNPs. Briefly, ENCODE Project data were quarried using the HaploReg v2 tool and eQTL analyses were performed taking advantage of data free available on GTEx Portal $[14,21]$. Among the three variants that were found associated with the risk of DTC in the combined analysis of all the European populations, rs6759952 (DIRC3) and rs10136427 (BATF) were found to map in regions of weak and 
strong enhancers. Both SNPs alter the binding sites for regulatory protein: rs6759952-T risk allele introduces the consensus sequence for Pou1f1, Pou2f2, TLX1 and YY1 proteins and rs10136427-C risk allele removes a FOXD3 site. Little support for the functional role of rs7267944 (DHX35) was found.

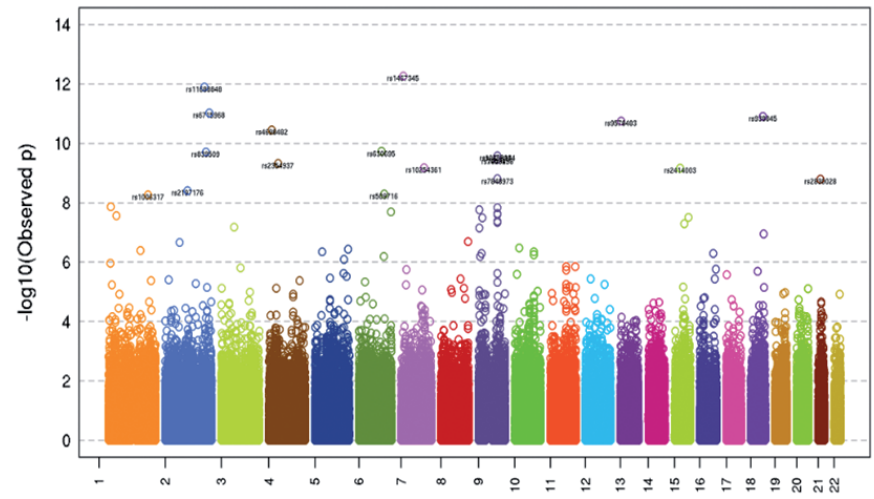

Fig. 1 - Manhattan plot of simple ${ }^{2}$ allelic test of association p-values from the GWAS. The plot shows the $-\log 10 p$-values for each tagSNP against chromosomal location. Values for each chromosome are reported in different colors for visual effect.
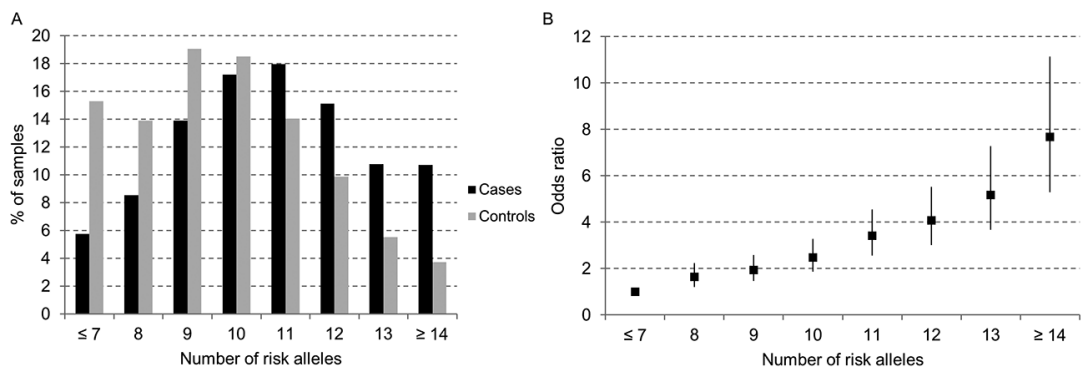

Fig. 2 - Cumulative risk assessment. (A) Sample distribution according to the number of risk alleles in eleven SNPs associated in the Italian DTC cases (black columns) and controls (grey columns). (B) Plot of the increasing ORs for DTC with increasing number of risk alleles. The category $\leq 7$ was chosen as reference $(\mathrm{OR}=1.0)$; vertical bars correspond to $95 \%$ confidence intervals.

A possible regulatory consequence was identified for all the SNPs associated with the disease only in the Italian population, except for rs1220597 (SPATA13). The variants rs7617304 (RARRES1), rs10238549 and rs7800391 (IMMP2L) and rs7935113 (GALNTL4) are 
Tab. 1 - Risk of differentiated thyroid cancer associated with single nucleotide polymorphisms identified in the present study. Significant results at a genome-wide level are highlighted in bold.

\begin{tabular}{|c|c|c|c|c|c|c|c|c|}
\hline SNP & Locus & $\begin{array}{l}\text { Closest } \\
\text { Gene }\end{array}$ & $\begin{array}{l}\text { Risk } \\
\text { allele }\end{array}$ & Population & $\begin{array}{l}\text { Number of } \\
\text { cases/controls }\end{array}$ & $\begin{array}{c}\text { Risk allele } \\
\text { frequency } \\
\text { (cases/controls }\end{array}$ & $\begin{array}{l}\text { Allelic OR } \\
(95 \% \text { CI })^{(*)}\end{array}$ & $p$-value ${ }^{(*)}$ \\
\hline \multirow{8}{*}{ rs 6759952} & \multirow{8}{*}{$2 \mathrm{q} 35$} & \multirow{8}{*}{ DIRC3 } & \multirow{8}{*}{$\mathrm{T}$} & GWAS & $649 / 431$ & $0.47 / 0.38$ & $1.44(1.21-1.72)$ & $4.7 \times 10^{-5}$ \\
\hline & & & & Italian1 & $1160 / 927$ & $0.49 / 0.42$ & $1.32(1.17-1.49)$ & $9.8 \times 10^{-6}$ \\
\hline & & & & Italian2 & $322 / 710$ & $0.44 / 0.40$ & $1.16(0.96-1.41)$ & 0.12 \\
\hline & & & & Polish & $413 / 420$ & $0.46 / 0.44$ & $1.07(0.88-1.30)$ & 0.48 \\
\hline & & & & Spanish & $397 / 393$ & $0.51 / 0.39$ & $1.58(1.29-1.93)$ & $8.2 \times 10^{-6}$ \\
\hline & & & & UK & $497 / 1090$ & $0.46 / 0.43$ & $1.14(0.98-1.32)$ & 0.09 \\
\hline & & & & Italian cohorts & $2131 / 2068$ & - & $1.30(1.18-1.43)$ & $7.3 \times 10^{-8}$ \\
\hline & & & & Joint analysis & $3438 / 3971$ & - & $\begin{array}{c}1.25(1.16-1.34) \\
P_{\text {het }} 0.03, I^{2}=58.5 \%\end{array}$ & $6.4 \times 10^{-10}$ \\
\hline \multirow{7}{*}{ rs 7617304} & \multirow{7}{*}{$3 \mathrm{q} 25.32$} & \multirow{7}{*}{ RARRESI } & \multirow{7}{*}{ A } & GWAS & $649 / 430$ & $0.31 / 0.25$ & $1.37(1.13-1.67)$ & $1.4 \times 10^{-3}$ \\
\hline & & & & Italian1 & $1170 / 933$ & $0.28 / 0.25$ & $1.16(1.01-1.34)$ & 0.03 \\
\hline & & & & Italian2 & $320 / 705$ & $0.31 / 0.27$ & $1.22(1.00-1.50)$ & 0.05 \\
\hline & & & & Polish & $437 / 431$ & $0.19 / 0.21$ & $0.92(0.73-1.17)$ & 0.50 \\
\hline & & & & Spanish & $388 / 394$ & $0.26 / 0.25$ & $1.09(0.87-1.37)$ & 0.47 \\
\hline & & & & Italian cohorts & $2139 / 2068$ & - & $1.25(1.12-1.39)$ & $4.6 \times 10^{-5}$ \\
\hline & & & & Joint analysis & $2964 / 2893$ & - & $\begin{array}{c}1.17(1.07-1.27) \\
P_{h e t=}=0.12, I^{2}=46.0 \%\end{array}$ & $7.0 \times 10^{-4}$ \\
\hline \multirow{7}{*}{$\begin{array}{c}\text { rs } 1318458 \\
7\end{array}$} & \multirow{7}{*}{$5 \mathrm{q} 14.1$} & \multirow{7}{*}{$A R S B$} & \multirow{7}{*}{ G } & GWAS & $646 / 414$ & $0.77 / 0.69$ & $1.51(1.24-1.83)$ & $3.60 \times 10^{-5}$ \\
\hline & & & & Italian $1+2$ & $1429 / 1541$ & $0.76 / 0.72$ & $1.19(1.06-1.33)$ & $4.15 \times 10^{-3}$ \\
\hline & & & & Polish & $442 / 434$ & $0.76 / 0.74$ & $1.10(0.88-1.36)$ & 0.41 \\
\hline & & & & Spanish & $382 / 403$ & $0.72 / 0.74$ & $0.91(0.73-1.14)$ & 0.42 \\
\hline & & & & Italian cohorts & $2075 / 1955$ & - & $1.28(1.15-1.43)$ & $8.54 \times 10^{-6}$ \\
\hline & & & & Joint analysis & $2899 / 2792$ & - & $1.17(1.07-1.27)$ & $7.16 \times 10^{-4}$ \\
\hline & & & & & & & $P_{\text {het }}=6.4 \times 10^{-3}, I^{2}=75.6 \%$ & \\
\hline \multirow{8}{*}{$\begin{array}{c}\text { rs1023854 } \\
9\end{array}$} & \multirow{8}{*}{$7 \mathrm{q} 21$} & \multirow{8}{*}{$I M M P 2 L$} & \multirow{8}{*}{$\mathrm{C}$} & GWAS & $649 / 431$ & $0.72 / 0.63$ & $1.48(1.23-1.77)$ & $3.2 \times 10^{-5}$ \\
\hline & & & & Italian1 & $1170 / 933$ & $0.68 / 0.64$ & $1.21(1.06-1.37)$ & $4.7 \times 10^{-3}$ \\
\hline & & & & Italian2 & $323 / 695$ & $0.71 / 0.68$ & $1.16(0.94-1.42)$ & 0.16 \\
\hline & & & & Polish & $451 / 438$ & $0.76 / 0.73$ & $1.17(0.94-1.45)$ & 0.16 \\
\hline & & & & Spanish & $390 / 391$ & $0.65 / 0.72$ & $0.73(0.59-0.91)$ & $4.4 \times 10^{-3}$ \\
\hline & & & & UK & $503 / 1101$ & $0.72 / 0.71$ & $1.02(0.86-1.20)$ & 0.85 \\
\hline & & & & Italian cohorts & $2142 / 2059$ & - & $1.27(1.15-1.40)$ & $4.1 \times 10^{-6}$ \\
\hline & & & & Joint analysis & $3486 / 3989$ & - & $\begin{array}{c}1.13(1.05-1.22) \\
P_{\text {het }}=2.0 \times 10^{-4}, I^{2}=79.5 \%\end{array}$ & $1.1 \times 10^{-3}$ \\
\hline & & & & GWAS & $649 / 430$ & $0.43 / 0.34$ & $1.45(1.21-1.73)$ & $5.2 \times 10^{-5}$ \\
\hline & & & & Italian 1 & $1165 / 934$ & $0.40 / 0.39$ & $1.22(1.07-1.38)$ & $2.3 \times 10^{-3}$ \\
\hline & & & & Italian2 & $320 / 679$ & $0.41 / 0.40$ & $1.06(0.87-1.28)$ & 0.55 \\
\hline 7800391 & 7021 & $M M P 2 I$ & $T$ & Polish & $444 / 422$ & $0.42 / 0.40$ & $1.06(0.88-1.29)$ & 0.53 \\
\hline $\mathrm{rs} / 800391$ & $7 \mathrm{q} 21$ & $I M M P 2 L$ & $\mathrm{~T}$ & Spanish & $407 / 394$ & $0.40 / 0.44$ & $0.86(0.71-1.05)$ & 0.14 \\
\hline & & & & Italian cohorts & $2134 / 2043$ & - & $1.25(1.14-1.38)$ & $5.7 \times 10^{-6}$ \\
\hline & & & & Joint analysis & $2985 / 2859$ & - & $\begin{array}{c}1.14(1.05-1.23) \\
P_{\text {het }} 5.0 \times 10^{-3}, I^{2}=73.1 \%\end{array}$ & $1.3 \times 10^{-3}$ \\
\hline & & & & GWAS & $649 / 431$ & $0.69 / 0.60$ & $1.51(1.23-1.86)$ & $7.9 \times 10^{-5}$ \\
\hline & & & & Italian1 & $1155 / 916$ & $0.67 / 0.63$ & $1.18(1.04-1.34)$ & 0.01 \\
\hline & & & & Italian2 & $322 / 706$ & $0.66 / 0.62$ & $1.20(0.98-1.46)$ & 0.07 \\
\hline rs 1078150 & & & $C$ & Polish & $404 / 424$ & $0.58 / 0.59$ & $0.99(0.81-1.21)$ & 0.91 \\
\hline 0 & $9 \mathrm{q} 34.3$ & SNAPC4 & $\mathrm{C}$ & Spanish & $386 / 392$ & $0.63 / 0.61$ & $1.09(0.89-1.34)$ & 0.42 \\
\hline & & & & Italian cohorts & $2126 / 2053$ & - & $1.23(1.12-1.36)$ & $3.5 \times 10^{-5}$ \\
\hline & & & & Joint analysis & $2916 / 2869$ & - & $\begin{array}{c}1.17(1.08-1.27) \\
P_{\text {het }}=0.18, I^{2}=36.6 \%\end{array}$ & $1.1 \times 10^{-4}$ \\
\hline & & & & GWAS & $647 / 431$ & $0.23 / 0.16$ & $1.50(1.20-1.88)$ & $3.26 \times 10^{-4}$ \\
\hline & & & & Italian1+2 & $1454 / 1572$ & $0.20 / 0.16$ & $1.28(1.12-1.46)$ & $2.20 \times 10^{-4}$ \\
\hline rs7935113 & $11 \mathrm{n} 153$ & GALNTL & $\mathrm{C}$ & Polish & $452 / 443$ & $0.13 / 0.13$ & $0.99(0.75-1.30)$ & 0.93 \\
\hline $\mathrm{rs} 7935113$ & $11 \mathrm{p} 15.3$ & 4 & C & Spanish & $352 / 407$ & $0.18 / 0.18$ & $1.02(0.78-1.32)$ & 0.90 \\
\hline & & & & Italian cohorts & $2101 / 2003$ & - & $1.36(1.20-1.53)$ & $7.41 \times 10^{-7}$ \\
\hline & & & & Joint analysis & $2905 / 2853$ & - & $1.24(1.12-1.38)$ & $2.71 \times 10^{-5}$ \\
\hline & & & & & & & $P_{h e t}=0.05, I^{2}=61.96$ & \\
\hline & & & & GWAS & $646 / 414$ & $0.48 / 0.39$ & $1.42(1.20-1.70)$ & $7.11 \times 10^{-5}$ \\
\hline & & & & Italian $1+2$ & $1458 / 1575$ & $0.47 / 0.43$ & $1.20(1.08-1.33)$ & $5.02 \times 10^{-4}$ \\
\hline & & & & Polish & $435 / 449$ & $0.44 / 0.43$ & $1.01(0.84-1.22)$ & 0.92 \\
\hline rs1220597 & $13 q 12.12$ & SPATA13 & $\mathrm{C}$ & Spanish & $332 / 407$ & $0.47 / 0.47$ & $1.00(0.82-1.23)$ & 0.99 \\
\hline & & & & Italian cohorts & $2104 / 1989$ & - & $1.26(1.14-1.38)$ & $3.25 \times 10^{-6}$ \\
\hline & & & & Joint analysis & $2871 / 2845$ & - & $1.16(1.07-1.25)$ & $2.64 \times 10^{-4}$ \\
\hline
\end{tabular}




\begin{tabular}{|c|c|c|c|c|c|c|c|c|}
\hline & & & & & & \multicolumn{3}{|c|}{$P_{h e c}=0.02, I^{2}=70.1 \%$} \\
\hline \multirow{7}{*}{$\begin{array}{c}\text { rs } 1013642 \\
7\end{array}$} & \multirow{7}{*}{$14 \mathrm{q} 24.3$} & \multirow{7}{*}{ BATF } & \multirow{7}{*}{$\mathrm{C}$} & GWAS & $646 / 414$ & $0.88 / 0.81$ & $1.62(1.28-2.06)$ & $5.73 \times 10^{-5}$ \\
\hline & & & & Italian1+2 & $1515 / 1598$ & $0.87 / 0.84$ & $1.26(1.09-1.45)$ & $1.32 \times 10^{-3}$ \\
\hline & & & & Polish & $458 / 444$ & $0.79 / 0.76$ & $1.19(0.95-1.48)$ & 0.12 \\
\hline & & & & Spanish & $380 / 406$ & $0.84 / 0.83$ & $1.05(0.81-1.37)$ & 0.72 \\
\hline & & & & Italian cohorts & $2158 / 2012$ & - & $1.40(1.23-1.60)$ & $4.35 \times 10^{-7}$ \\
\hline & & & & Joint analysis & $2999 / 2862$ & - & $1.30(1.17-1.44)$ & $9.30 \times 10^{-7}$ \\
\hline & & & & & & & $P_{\text {he }}=0.12, I^{2}=49.1 \%$ & \\
\hline \multirow{7}{*}{ rs 1203952} & \multirow{7}{*}{ 20p11 } & \multirow{7}{*}{ FOXA2 } & \multirow{7}{*}{ G } & GWAS & $647 / 429$ & $0.28 / 0.21$ & $1.49(1.21-1.83)$ & $1.37 \times 10^{-4}$ \\
\hline & & & & Italian $1+2$ & $1453 / 1514$ & $0.27 / 0.23$ & $1.25(1.11-1.41)$ & $2.10 \times 10^{-4}$ \\
\hline & & & & Polish & $453 / 437$ & $0.21 / 0.23$ & $0.88(0.70-1.10)$ & 0.25 \\
\hline & & & & Spanish & $351 / 404$ & $0.23 / 0.21$ & $1.10(0.86-1.40)$ & 0.44 \\
\hline & & & & Italian cohorts & $2100 / 1943$ & - & $1.29(1.16-1.44)$ & $4.42 \times 10^{-6}$ \\
\hline & & & & Joint analysis & $2904 / 2784$ & - & $1.20(1.09-1.31)$ & $1.20 \times 10^{-4}$ \\
\hline & & & & & & & $P_{\text {hei }}=6.1 \times 10^{-3}, I^{2}=75.80$ & \\
\hline \multirow{7}{*}{ rs 7267944} & \multirow{7}{*}{$\begin{array}{l}\text { 20q11.22- } \\
\text { q12 }\end{array}$} & \multirow{7}{*}{ DHX35 } & \multirow{7}{*}{$\mathrm{C}$} & GWAS & $646 / 414$ & $0.26 / 0.18$ & $1.54(1.24-1.90)$ & $6.60 \times 10^{-5}$ \\
\hline & & & & Italian $1+2$ & $1477 / 1601$ & $0.23 / 0.19$ & $1.29(1.14-1.45)$ & $5.83 \times 10^{-5}$ \\
\hline & & & & Polish & $454 / 442$ & $0.17 / 0.16$ & $1.10(0.85-1.41)$ & 0.45 \\
\hline & & & & Spanish & $374 / 406$ & $0.21 / 0.18$ & $1.23(0.96-1.57)$ & 0.11 \\
\hline & & & & Italian cohorts & $2123 / 2015$ & - & $1.39(1.24-1.56)$ & $2.13 \times 10^{-8}$ \\
\hline & & & & Joint analysis & $2951 / 2863$ & - & $1.32(1.20-1.46)$ & $1.34 \times 10^{-8}$ \\
\hline & & & & & & & $P_{\text {her }}=0.18, I^{2}=38.6 \%$ & \\
\hline
\end{tabular}

Tab. 2 - eQTL analysis based on Genotype-Tissue Expression (GTEx) program data. Significant results on thyroid tissues are highlighted in bold. Up=up-regulation, Down=down-regulation.

\begin{tabular}{|c|c|c|c|c|c|c|c|}
\hline SNP & $\begin{array}{c}\text { SNP } \\
\text { locus }\end{array}$ & $\begin{array}{l}\text { Risk } \\
\text { allele }\end{array}$ & Gene & $\begin{array}{l}\text { Gene } \\
\text { locus }\end{array}$ & p-value & $\begin{array}{c}\text { Risk allele } \\
\text { effect on gene } \\
\text { expression }\end{array}$ & Tissue \\
\hline rs6759952 & $2 \mathrm{q} 35$ & $\mathrm{~T}$ & DIRC3 & $2 \mathrm{q} 35$ & $2.2 \times 10^{-7}$ & $\mathrm{Up}$ & Testis \\
\hline \multirow{17}{*}{ rs7617304 } & \multirow{17}{*}{$3 \mathrm{q} 25.32$} & \multirow{17}{*}{ A } & GFMI & $3 q 25.32$ & $2.5 \times 10^{-5}$ & Down & Pancreas \\
\hline & & & $L X N$ & $3 \mathrm{q} 25.32$ & $7.0 \times 10^{-5}$ & Up & Cells - Transformed fibroblasts \\
\hline & & & $M L F 1$ & $3 \mathrm{q} 25.32$ & $8.7 \times 10^{-6}$ & Up & Heart - Left Ventricle \\
\hline & & & RP11-379F4.4 & $3 \mathrm{q} 25.32$ & $1.3 \times 10^{-6}$ & Down & Adipose - Visceral (Omentum) \\
\hline & & & RP11-379F4.4 & $3 \mathrm{q} 25.32$ & $2.4 \times 10^{-5}$ & Down & Adrenal Gland \\
\hline & & & $R P 11-379 F 4.4$ & $3 \mathrm{q} 25.32$ & $3.5 \times 10^{-6}$ & Down & Artery - Aorta \\
\hline & & & $R P 11-379 F 4.4$ & $3 q 25.32$ & $4.9 \times 10^{-5}$ & Down & Artery - Tibial \\
\hline & & & $R P 11-379 F 4.4$ & $3 q 25.32$ & $6.2 \times 10^{-5}$ & Down & Colon - Sigmoid \\
\hline & & & $R P 11-379 F 4.4$ & $3 \mathrm{q} 25.32$ & $7.0 \times 10^{-6}$ & Down & Esophagus - Gastroesophageal Junction \\
\hline & & & $R P 11-379 F 4.4$ & $3 q 25.32$ & $2.6 \times 10^{-9}$ & Down & Lung \\
\hline & & & RP11-379F4.4 & $3 \mathrm{q} 25.32$ & $4.7 \times 10^{-6}$ & Down & Nerve - Tibial \\
\hline & & & RP11-379F4.4 & $3 \mathrm{q} 25.32$ & $4.7 \times 10^{-10}$ & Down & Skin - Not Sun Exposed (Suprapubic) \\
\hline & & & RP11-379F4.4 & $3 \mathrm{q} 25.32$ & $9.5 \times 10^{-10}$ & Down & Skin - Sun Exposed (Lower leg) \\
\hline & & & RP11-379F4.4 & $3 \mathrm{q} 25.32$ & $2.6 \times 10^{-12}$ & Down & Testis \\
\hline & & & RP11- & $3 q 25.32$ & $9.3 \times 10^{-11}$ & Down & Thyroid \\
\hline & & & RP11-379F4.7 & $3 \mathrm{q} 25.32$ & $5.2 \times 10^{-6}$ & Up & Nerve - Tibial \\
\hline & & & RP11-379F4.8 & $3 \mathrm{q} 25.32$ & $3.1 \times 10^{-7}$ & Down & Testis \\
\hline rs7800391 & $7 \mathrm{q} 21$ & $\mathrm{~T}$ & $A C 003088.1$ & $7 \mathrm{q} 31.1$ & $2.2 \times 10^{-20}$ & Down & Cells - Transformed fibroblasts \\
\hline \multirow{20}{*}{ rs 10781500} & \multirow{20}{*}{$9 \mathrm{q} 34.3$} & \multirow{20}{*}{$\mathrm{C}$} & CARD9 & $9 \mathrm{q} 34.3$ & $8.4 \times 10^{-7}$ & Up & Cells - Transformed fibroblasts \\
\hline & & & CARD 9 & $9 \mathrm{q} 34.3$ & $1.0 \times 10^{-18}$ & Down & Whole Blood \\
\hline & & & GPSMI & $9 \mathrm{q} 34.3$ & $3.0 \times 10^{-5}$ & Up & Muscle - Skeletal \\
\hline & & & GPSM1 & $9 q 34.3$ & $2.0 \times 10^{-5}$ & Up & Thyroid \\
\hline & & & INPP5E & $9 \mathrm{q} 34.3$ & $1.9 \times 10^{-7}$ & Up & Brain - Caudate (basal ganglia) \\
\hline & & & INPP5E & $9 \mathrm{q} 34.3$ & $1.7 \times 10^{-7}$ & Up & Brain - Cerebellum \\
\hline & & & INPP5E & $9 \mathrm{q} 34.3$ & $2.1 \times 10^{-5}$ & Up & Esophagus - Mucosa \\
\hline & & & INPP5E & $9 \mathrm{q} 34.3$ & $2.3 \times 10^{-5}$ & Up & Lung \\
\hline & & & INPP5E & $9 \mathrm{q} 34.3$ & $3.4 \times 10^{-6}$ & Up & Skin - Sun Exposed (Lower leg) \\
\hline & & & INPP5E & $9 \mathrm{q} 34.3$ & $1.6 \times 10^{-9}$ & Up & Testis \\
\hline & & & INPP5E & $9 \mathrm{q} 34.3$ & $5.3 \times 10^{-28}$ & Up & Thyroid \\
\hline & & & PMPCA & $9 \mathrm{q} 34.3$ & $7.8 \times 10^{-6}$ & Down & Liver \\
\hline & & & PMPCA & $9 \mathrm{q} 34.3$ & $4.1 \times 10^{-8}$ & Up & Thyroid \\
\hline & & & SDCCAG3 & $9 \mathrm{q} 34.3$ & $2.1 \times 10^{-5}$ & Up & Artery - Tibial \\
\hline & & & SDCCAG3 & $9 \mathrm{q} 34.3$ & $1.1 \times 10^{-5}$ & Up & Cells - Transformed fibroblasts \\
\hline & & & SDCCAG3 & $9 q 34.3$ & $1.8 \times 10^{-5}$ & Up & Thyroid \\
\hline & & & SDCCAG3 & $9 \mathrm{q} 34.3$ & $2.0 \times 10^{-10}$ & Up & Whole Blood \\
\hline & & & SEC16A & $9 \mathrm{q} 34.3$ & $1.4 \times 10^{-5}$ & Up & Pancreas \\
\hline & & & SEC16A & $9 \mathrm{q} 34.3$ & $2.2 \times 10^{-11}$ & $\mathrm{Up}$ & Whole Blood \\
\hline & & & SNAPC4 & $9 \mathrm{q} 34.3$ & $3.9 \times 10^{-6}$ & Down & Whole Blood \\
\hline \multirow{3}{*}{ rs1203952 } & \multirow{3}{*}{$20 \mathrm{p} 11$} & \multirow{3}{*}{ G } & FOXA2 & 20p11 & $1.6 \times 10^{-18}$ & Down & Thyroid \\
\hline & & & LINC00261 & 20p11 & $3.6 \times 10^{-11}$ & Down & Thyroid \\
\hline & & & RP4- & 20 p11 & $5.0 \times 10^{-17}$ & Down & Thyroid \\
\hline
\end{tabular}


5p15.33, 6q14.1, 10q26.12, 10q24.33 and 15q22.33 emerged as novel DTC risk factors $[22,23]$. However, current evidence from available GWASs explains only a small proportion of the disease heritability. Several explanations for the missing heritability were proposed. These included rare variants in novel pathways that are undetectable through traditional GWAS study design, structural variants, such as CNVs, that are poorly captured by existing technologies, insufficient power to detect gene-gene interactions and environmental factors. Thus, further studies on large sample sets and based on novel experimental approaches, as array-based fine-mapping, next generation sequencing and gene- environment association studies, are warranted to identify the predisposing factors that could explain a greater percentage of DTC heritability.

\section{ACKNOWLEDGEMENTS}

The authors are grateful to the study participants and the study investigators and coordinators for the recruitment of samples. This study was supported by the Associazione Italiana Ricerca sul Cancro (AIRC, 2008) and by the Istituto Toscano Tumori (ITT, 2010).

\section{REFERENCES}

[1] Sipos JA, Mazzaferri EL, Thyroid cancer epidemiology and prognostic variables, Clin Oncol (R Coll Radiol), 2010:22:395-404.

[2] Grande E, Diez JJ, Zafon C, Capdevila J, Thyroid cancer: molecular aspects and new therapeutic strategies, J Thyroid Res, 2012:2012:847108.

[3] Dal Maso L, Bosetti C, La Vecchia C, Franceschi S, Risk factors for thyroid cancer: an epidemiological review focused on nutritional factors, Cancer Causes Control, 2009:20:75-86.

[4] Fallah M, Pukkala E, Tryggvadottir L, Olsen JH, Tretli S, Sundquist K, Hemminki K, Risk of thyroid cancer in first-degree relatives of patients with non-medullary thyroid cancer by histology type and age at diagnosis: a joint study from five Nordic countries, J Med Genet, 2013:50:373-382.

[5] Landa I, Robledo M, Association studies in thyroid cancer susceptibility: are we on the right track?, J Mol Endocrinol, 2011:47:R43-58.

[6] Figlioli G, Elisei R, Romei C, Melaiu O, Cipollini M, Bambi F, Chen B, Kohler A, Cristaudo A, Hemminki K, Gemignani F, Forsti A, Landi S, A Comprehensive Meta-analysis of Case-Control Association Studies to Evaluate 
Polymorphisms Associated with the Risk of Differentiated Thyroid Carcinoma, Cancer Epidemiol Biomarkers Prev, 2016:25:700-713.

[7] Kruglyak L, The road to genome-wide association studies, Nat Rev Genet, 2008:9:314-318.

[8] Hirschhorn JN, Daly MJ, Genome-wide association studies for common diseases and complex traits, Nat Rev Genet, 2005:6:95-108.

[9] Hosking FJ, Dobbins SE, Houlston RS, Genome-wide association studies for detecting cancer susceptibility, Br Med Bull, 2011:97:27-46.

[10] Cooper GM, Shendure J, Needles in stacks of needles: finding disease-causal variants in a wealth of genomic data, Nat Rev Genet, 2011:12:628-640.

[11] Consortium EP, The ENCODE (ENCyclopedia Of DNA Elements) Project, Science, 2004:306:636-640.

[12] Rockman MV, Kruglyak L, Genetics of global gene expression, Nat Rev Genet, 2006:7:862-872.

[13] Stranger BE, Forrest MS, Clark AG, Minichiello MJ, Deutsch S, Lyle R, Hunt S, Kahl B, Antonarakis SE, Tavare S, Deloukas P, Dermitzakis ET, Genome-wide associations of gene expression variation in humans, PLoS Genet, 2005:1:e78.

[14] Consortium GT, Human genomics. The Genotype-Tissue Expression (GTEx) pilot analysis: multitissue gene regulation in humans, Science, 2015:348:648-660.

[15] Gudmundsson J, Sulem P, Gudbjartsson DF, Jonasson JG, Sigurdsson A Bergthorsson JT, He H, Blondal T, Geller F, Jakobsdottir M, Magnusdottir DN, Matthiasdottir S, Stacey SN, Skarphedinsson OB, Helgadottir H, Li W, Nagy R, Aguillo E, Faure E, Prats E, Saez B, Martinez M, Eyjolfsson GI, Bjornsdottir US, Holm H, Kristjansson K, Frigge ML, Kristvinsson H, Gulcher JR, Jonsson T, Rafnar T, Hjartarsson H, Mayordomo JI, de la Chapelle A, Hrafnkelsson J, Thorsteinsdottir U, Kong A, Stefansson K, Common variants on 9q22.33 and 14q13.3 predispose to thyroid cancer in European populations, Nat Genet, 2009:41:460-464.

[16] Takahashi M, Saenko VA, Rogounovitch TI, Kawaguchi T, Drozd VM, Takigawa-Imamura H, Akulevich NM, Ratanajaraya C, Mitsutake N, Takamura N, Danilova LI, Lushchik ML, Demidchik YE, Heath S, Yamada R, Lathrop M, Matsuda F, Yamashita S, The FOXE1 locus is a major genetic determinant for radiation-related thyroid carcinoma in Chernobyl, Hum Mol Genet, 2010:19:2516-2523.

[17] Gudmundsson J, Sulem P, Gudbjartsson DF, Jonasson JG, Masson G, He H, Jonasdottir A, Sigurdsson A, Stacey SN, Johannsdottir H, Helgadottir HT, Li W, Nagy R, Ringel MD, Kloos RT, de Visser MC, Plantinga TS, den Heijer M, Aguillo E, Panadero A, Prats E, Garcia-Castano A, De Juan A, Rivera F, Walters GB, Bjarnason H, Tryggvadottir L, Eyjolfsson GI, Bjornsdottir US, Holm H, Olafsson I, Kristjansson K, Kristvinsson H, Magnusson OT, Thorleifsson G, Gulcher JR, Kong A, Kiemeney LA, Jonsson T, Hjartarson H, Mayordomo JI, Netea-Maier RT, de la Chapelle A, Hrafnkelsson J, Thorsteinsdottir U, Rafnar T, Stefansson K, Discovery of common variants associated with low TSH levels and thyroid cancer risk, Nat Genet, 2012:44:319-322.

[18] Kohler A, Chen B, Gemignani F, Elisei R, Romei C, Figlioli G, Cipollini M, 
Cristaudo A, Bambi F, Hoffmann P, Herms S, Kalemba M, Kula D, Harris S, Broderick P, Houlston R, Pastor S, Marcos R, Velazquez A, Jarzab B, Hemminki K, Landi S, Forsti A, Genome-wide association study on differentiated thyroid cancer, J Clin Endocrinol Metab, 2013:98:E1674-1681.

[19] Figlioli G, Chen B, Elisei R, Romei C, Campo C, Cipollini M, Cristaudo A, Bambi F, Paolicchi E, Hoffmann P, Herms S, Kalemba M, Kula D, Pastor S, Marcos R, Velazquez A, Jarzab B, Landi S, Hemminki K, Gemignani F, Forsti A, Novel genetic variants in differentiated thyroid cancer and assessment of the cumulative risk, Sci Rep, 2015:5:8922.

[20] Figlioli G, Kohler A, Chen B, Elisei R, Romei C, Cipollini M, Cristaudo A, Bambi F, Paolicchi E, Hoffmann P, Herms S, Kalemba M, Kula D, Pastor S, Marcos R, Velazquez A, Jarzab B, Landi S, Hemminki K, Forsti A, Gemignani F, Novel genome-wide association study-based candidate loci for differentiated thyroid cancer risk, J Clin Endocrinol Metab, 2014:99:E2084-2092.

[21] Ward LD, Kellis M, HaploReg: a resource for exploring chromatin states, conservation, and regulatory motif alterations within sets of genetically linked variants, Nucleic Acids Res, 2012:40:D930-934.

[22] Gudmundsson J, Thorleifsson G, Sigurdsson JK, Stefansdottir L, Jonasson JG, Gudjonsson SA, Gudbjartsson DF, Masson G, Johannsdottir H, Halldorsson GH, Stacey SN, Helgason H, Sulem P, Senter L, He H, Liyanarachchi S, Ringel MD, Aguillo E, Panadero A, Prats E, Garcia-Castano A, De Juan A, Rivera F, $\mathrm{Xu}$ L, Kiemeney LA, Eyjolfsson GI, Sigurdardottir O, Olafsson I, Kristvinsson H, Netea-Maier RT, Jonsson T, Mayordomo JI, Plantinga TS, Hjartarson H, Hrafnkelsson J, Sturgis EM, Thorsteinsdottir U, Rafnar T, de la Chapelle A, Stefansson K, A genome-wide association study yields five novel thyroid cancer risk loci, Nat Commun, 2017:8:14517.

[23] Mancikova V, Cruz R, Inglada-Perez L, Fernandez-Rozadilla C, Landa I, Cameselle-Teijeiro J, Celeiro C, Pastor S, Velazquez A, Marcos R, Andia V, Alvarez-Escola C, Meoro A, Schiavi F, Opocher G, Quintela I, Ansede-Bermejo J, Ruiz-Ponte C, Santisteban P, Robledo M, Carracedo A, Thyroid cancer GWAS identifies 10q26.12 and 6q14.1 as novel susceptibility loci and reveals genetic heterogeneity among populations, Int J Cancer, 2015:137:1870-1878. 